\title{
Analisis Ketersediaan Obat pada era Jaminan Kesehatan Nasional di Apotek Wilayah Bojonegara Kotamadya Bandung Tahun 2015
}

\author{
Aditya Nugraha Nurtantijo, ${ }^{1}$ Kuswinarti, ${ }^{2}$ Deni Kurniadi Sunjaya ${ }^{3}$ \\ ${ }^{1}$ Fakultas Kedokteran Universitas Padjadjaran, \\ ${ }^{2}$ Departemen Farmakologi dan Terapi, Fakultas Kedokteran, Universitas Padjadjaran, \\ ${ }^{3}$ Departemen Ilmu Kesehatan Masyarakat, Fakultas Kedokteran, Universitas Padjadjaran
}

\begin{abstract}
Abstrak
Reformasi dalam bentuk sistem pembiayaan kesehatan di Indonesia diresmikan pada 1 Januari 2014. Asuransi kesehatan sosial berbentuk Jaminan Kesehatan Nasional (JKN) saat ini dianggap masih memiliki kekurangan, salah satunya adalah ketersediaan obat dalam sektor swasta, yaitu apotek. Sementara itu belum ada data mengenai ketersediaan obat JKN di apotek. Penelitian ini bertujuan untuk mengetahui dampak perubahan sistem pembiayaan kesehatan terhadap ketersediaan obat, serta faktor-faktor yang memengaruhinya di apotek rujukan. Penelitian menggunakan desain kualitatif yang diolah dengan proses pengkodean, kategorisasi, penyusunan tema, dan sintesis teori untuk mendapatkan informasi secara menyeluruh dari apotek dan pasien yang terkait dengan JKN. Subjek penelitian adalah 10 orang yang merupakan manajer, petugas pencatatan, asisten apoteker, dan pasien. Penelitian dilakukan di apotek rujukan JKN di wilayah Bojonegara Kotamadya Bandung pada tahun 2015. Hasil penelitian menunjukkan adanya dampak dari perubahan kebijakan sistem pembiayaan berupa ketidaksesuaian atau penyimpangan antara lain berupa ketidaktersediaan obat dan kerugian yang ditanggung apotek yang dipengaruhi oleh aspek regulasi, pengadaan obat, sosialisasi, dan manajemen. Ketidaktersediaan obat dalam penelitian ini memberikan gambaran mengenai respon dalam reformasi. Aspek penting dalam perubahan adalah persiapan, serta respon dari pelaksana perubahan tersebut. Keterbatasan penelitian ini adalah jumlah apotek dan subjek yang terbatas.
\end{abstract}

Kata Kunci : Apotek, Jaminan Kesehatan Nasional, Ketersediaan Obat

\section{Analysis of Drug Availability at Era National Health Insurance in Pharmacies Located in Bojonegara Area City of Bandung 2015}

\begin{abstract}
Reformation in health financing system in Indonesia was initialized on January 1st, 2014. Social health insurance in the form of National Health Insurance (Jaminan Kesehatan Nasional/JKN) is currently considered has flaws in its system. One of which is the availability of drugs in the private sector, pharmacies. Meanwhile there is currently no data on the availability of drugs. This study learn the impact of changes in the health system to the availability of drugs, and the factors that influence it. The study used qualitative design which include coding, categorization, constructing theme, pattern matching, and theorizing to obtain comprehensive information from pharmacies and patients associated with JKN. Subject of the study was 10 persons who are manager, administration officer, pharmacist assistant, and patient associated with JKN. This study conducted in pharmacies related to JKN in Bojonegara Area, City of Bandung, 2015. The results showed the impact of mismatches that arise in the implementation of changes in the form of deviations from the goal.In this study, the deviation in the form of non-availability of drugs and the harm done to pharmacies that are affected by regulatory aspects, drug provision, dissemination, and management. Non-availability of drugs in this study describe response of change. Important aspects in changes is preparation, and response of the population. Limitation of this study is limited number of pharmacies and subjects in the area.
\end{abstract}

Keywords : Pharmacy, National Health Insurance, Drugs Availability

Korespondensi:

Aditya Nugraha Nurtantijo

Fakultas Kedokteran Universitas Padjadjaran

Jl. Prof. Dr. Eyckman No. 38 Bandung 40161

Mobile : 081572022000

Email : adityanugrahanurtantijo@gmail.com 


\section{Pendahuluan}

Deklarasi Perserikatan Bangsa-Bangsa tahun 1948 mengakui bahwa tingkat hidup yang memadai untuk kesehatan dan kesejahteraan diri dan keluarga merupakan hak asasi manusia. Sidang ke 58 tahun 2005 di Jenewa, World Health Assembly (WHA) menggarisbawahi perlunya pengembangan sistem pembiayaan kesehatan yang menjamin tersedianya akses masyarakat terhadap pelayanan kesehatan dan memberikan perlindungan terhadap risiko keuangan. WHA kemudian mengeluarkan resolusi yang menyatakan, pembiayaan kesehatan yang berkelanjutan melalui Universal Health Coverage diselenggarakan melalui mekanisme asuransi kesehatan sosial. Pemerintah Indonesia mewujudkannya dalambentuk Jaminan Kesehatan Nasional (JKN) bagi kesehatan perorangan. ${ }^{1}$

Jaminan Kesehatan Nasional merupakan jaminan sosial wajib bagi seluruh penduduk Indonesia. Undang-Undang No.24 Tahun 2011 juga menetapkan Badan Penyelenggara Jaminan Sosial (BPJS) sebagai penyelenggara dari Jaminan Kesehatan Nasional. BPJS yang menjadi penyelenggara dari program tersebut merupakan gabungan dari beberapa badan penyelenggara yang selama ini memberikan asuransi kesehatan bagi pihak-pihak yang berbeda. BPJS sendiri terbagi dua menjadi BPJS Kesehatan dan BPJS Ketenagakerjaan. BPJS Kesehatan menjamin masyarakat umum sementara BPJS Ketenagakerjaan mengurusi urusan keselamatan kerja. ${ }^{2}$

Saat ini masih banyak keluhan dari Peserta JKN dalam pelayanan kesehatan yang mereka terima. Banyak peserta, khususnya yang berpenyakit kronis, mengeluhkan obat yang mereka terima hanya untuk konsumsi 3-7 hari, padahal sebelumnya peserta bisa memperoleh obat untuk 30 hari. Direktur Pelayanan BPJS Kesehatan, Fajriadinur, mengatakan masalah ini berkaitan dengan pola pembayaran BPJS Kesehatan ke fasilitas kesehatan rujukan yang belum mengakomodasi penyakit kronis tertentu. Dalam beberapa kasus yang terjadi, obat yang dibutuhkan tidak tersedia dan peserta BPJS harus menunggu beberapa hari bahkan beberapa minggu untuk mengambil obatnya. Hal ini menjadi masalah bagi peserta BPJS baik dari segi kenyamanan maupun segi finansial apalagi kalau tempat tinggal peserta jauh dari apotek sehingga peserta perlu mengeluarkan uang lebih untuk transport. Banyak peserta BPJS yang mempertanyakan ketersediaan obat JKN di apotek rujukan. Sementara itu belum diketahui adanya data ketersediaan obat BPJS di apotek-apotek tersebut.

Tujuan penelitian ini adalah mengetahui dampak perubahan sistem pembiayaan kesehatan terhadap ketersediaan obat JKN di apotek-apotek di Wilayah Bojonegara Kotamadya Bandung. Hasil penelitian ini diharapkan dapat mengetahui dampak perubahan sistem pembiayaan kesehatan terhadap ketersediaan obat JKN di apotek-apotek di Wilayah Bojonegara Kotamadya Bandung.

\section{Metode}

Penelitian dilakukan di apotek di Wilayah Bojonegara, Kotamadya Bandung pada tahun 2015. Penelitian ini menggunakan desain kualitatif dengan menggunakan indepth interview (wawancara mendalam). Metode ini dipilih agar informasi yang didapat meliputi semua aspek yang memengaruhi ketersediaan obat secara rinci dan mendalam. ${ }^{3}$ Data yang diambil merupakan data primer dari subjek penelitian berupa hasil wawancara.

Subjek penelitian sebanyak 10 orang yang terdiri atas 2 orang manajer, 2 orang petugas pencatatan, 2 orang asisten apoteker, dan 4 orang pasien dari 2 apotek di Wilayah Bojonegara, Kotamadya Bandung. Pemilihan subjek penelitian menggunakan metode purposive sampling yang merupakan non probability sampling. ${ }^{4}$ Subjek merupakan pegawai sah atau pasien dari Jaminan Kesehatan Nasional di apotek Wilayah Bojonegara Kotamadya Bandung. Kriteria eksklusi adalah jika subjek menolak untuk diikutsertakan dalam penelitian. Pengolahan data in-depth interview menggunakan teknik analisis Miles dan Huberman yang meliputi 3 tahapan, yaitu reduksi data (data reduction), penyajian data (data display), dan pengambilan kesimpulan/ verifikasi (conclusion drawing/verification). ${ }^{5}$

Penelitian ini telah disetujui oleh Komisi Etik Penelitian Kesehatan dari Kementrian Riset, Teknologi dan Pendidikan Tinggi Fakultas Kedokteran Universitas Padjadjaran dengan nomor 684/UN6.C1.3.2/KEPK/PN/2015.

\section{Hasil}

Hasil penelitian yang didapat dari wawancara mendalam dengan narasumber menghasilkan kesimpulan sebagai berikut :

Perubahan Sistem; Perubahan sistem yang terjadi merupakan perubahan sistem pembiayaan kesehatan. Perubahan ini tidak didukung dengan persiapan yang matang dari berbagai aspek. Ketidaksiapan dalam perubahan ini memicu pelaksanaan yang tidak efektif dan efisien yang akan dijelaskan lebih lanjut.

Ketidaksesuaian; Hal pertama yang muncul 


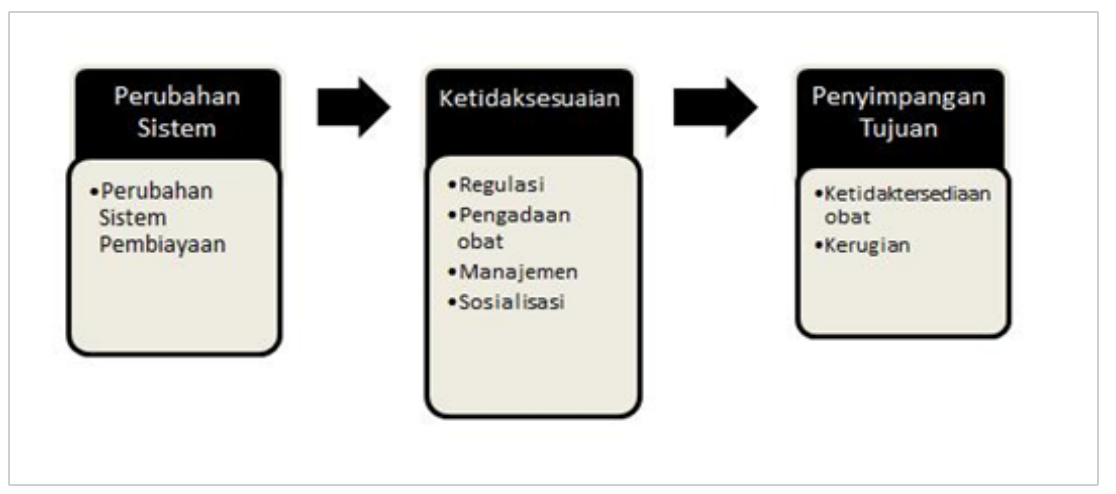

\section{Gambar 1 Hasil Penelitian}

saat ada perubahan adalah penolakan (resistance). Penolakan ini muncul dalam berbagai bentuk, antara lain ketidaksesuaian dan ketidakharmonisan. Dari hasil wawancara yang didapat, banyak bentuk ketidaksesuaian yang muncul dari perubahan sistem ini. Regulasi; Menurut hasil wawancara, peraturan yang diberikan BPJS dinilai kurang jelas dan tidak bertanggung jawab. Petugas administrasi di apotek menyampaikan bahwa ada kejadian saat BPJS mengirimkan peraturan yang berlaku terhitung Maret 2015, tetapi surat diterima pada tanggal 6 Juni 2015. Keterlambatan pemberitahuan ini menyebabkan kerugian sebesar 82 juta pada bulan tersebut karena banyak klaim obat yang tidak diterima oleh BPJS. Seorang pasien juga menyampaikan ketidaktahuannya mengenai peraturan BPJS terutama di bagian persyaratan obat. Sebagaimana disampaikan oleh pasien tersebut, "Saya bingung mau nyari di mana infonya, kadang udah dateng tapi malah ditolak sama apotek. Katanya hasil labnya udah gak berlaku. Padahal udah dicap di rumah sakit." Pengadaan Obat; Apotek rujukan atau jejaring berkewajiban menyediakan obat-obat formularium nasional (fornas) untuk keperluan pasien BPJS ini. Pengadaan obat oleh apotek ini dilakukan melalui e-purchasing berdasarkan e-catalogue dari Industri Farmasi pemenang tender melalui Pedagang Besar Farmasi (PBF). Harga obat e-catalogue ini jauh lebih murah dibandingkan harga obat Askes atau normal.

Manajer dari apotek di wilayah penelitian menyampaikan penilaiannya terhadap penyedia obat. Saat ditanya beliau menjawab, "Tapi kendala di kenyataan banyak yang sudah dapat tender tapi tidak mengeluarkan barang. Saya juga kurang tahu kenapa, tanya PBF (Pedagang Besar Farmasi) langsung aja." Saat diwawancara pada bulan November 2015, beliau menyatakan bahwa terhitung April 2014 hanya sekali saja beliau mendapatkan kiriman obat dari penyedia tersebut. Alasannya karena obatnya sedang kosong. Hal tersebut memaksa beliau untuk mencari obat di tempat lain, padahal ada selisih harga yang lebih mahal jika membeli dari penyedia lain. Manajemen; Perubahan sistem memaksa adanya perubahan manajemen. Selain membentuk manajemen baru berupa Badan Penyelenggara Jaminan Sosial, terjadi perubahan manajemen di rumah sakit dan apotek.

Dari hasil wawancara, tidak ditemukan perubahan pada jumlah pegawai. Tetapi, terjadi penambahan pekerjaan bagi pegawai di apotek. Pekerjaan itu antara lain penyuluhan di puskesmas.

Di rumah sakit, permasalahan terbesar muncul dari manajemen BPJS. Sebagaimana disampaikan oleh asisten apoteker yang diwawancara, "Banyak banget pasien datang udah dicap sama BPJS, tapi sebenarnya obat itu gak sesuai sama persyaratan yang diberikan BPJS ke kita, akhirnya terpaksa kita tolak." BPJS center di rumah sakit dinilai masih kurang dalam memilah resep mana yang sesuai dengan persyaratan BPJS. Salah satu faktor yang menyebabkan ini karena pasien BPJS di rumah sakit terlalu banyak. Sosialisasi; sosialisasi yang dilakukan BPJS dinilai masih belum cukup untuk memberikan informasi kepada semua pihak.

Terhadap apotek sosialisasi sering terlambat, sosialisasi terhadap dokter dinilai masih kurang sehingga terjadi permasalahan dalam peresepan dokter dan persyaratan dari BPJS yang harus dipenuhi tidak dijalankan. Sosialisasi untuk pasien dinilai masih kurang karena banyak pasien yang tidak mengerti peraturan JKN, terutama dalam hal obat yang mereka terima dan persyaratan seperti tes penunjang.

Penyimpangan Tujuan; Ketersediaan obat tidak tersedianya obat dari penyedia menyebabkan tidak tersedianya obat dengan harga khusus pasien JKN. Secara teknis, obat tersedia di stok apotek, tetapi bukan dari penyedia pemenang tender sehingga harganya berbeda. Selisih harga 
dapat menyebabkan kerugian jika obat tersebut digunakan untuk peserta JKN. Obat yang tidak tersedia dengan harga JKN berdasarkan hasil wawancara adalah amlodipine dan metformin. Kedua obat tersebut merupakan obat dengan permintaan tertinggi. Selain itu pada bulan November 2015 terjadi kekosongan glimepirid. Kerugian; apotek-apotek yang bekerjasama di Wilayah Bojonegara tergabung dalam satu jaringan apotek. Data dari apotek pusat menunjukkan angka kerugian yang tidak sedikit setiap bulannya. Klaim yang ditolak BPJS menunjukkan angka kerugian sebesar 82 juta pada bulan Juni 2015 dan 10 juta pada satu bulan lainnya di tahun 2015. Karena jaringan apotek yang cukup besar, apotek ini masih dapat menanggung kerugian.

Dari hasil penelitian ini dapat dilihat bahwa persiapan merupakan unsur penting dalam perubahan. Persiapan yang memadai dapat meningkatkan kualitas kerjasama (cooperation). Sebaliknya, persiapan yang kurang dapat meningkatkan perlawanan (resistance) terhadap perubahan tersebut. Akan tetapi sikap kooperatif atau perlawanan tersebut dapat berubah dalam proses perubahan tersebut. Faktor yang memengaruhi perubahan tersebut antara lain:

Informasi (Information); informasi merupakan salah satu komponen penting dalam peningkatan kerjasama dalam perubahan. Informasi yang baik akan memberikan gambaran apa yang berubah, mengapa harus berubah, kapan harus berubah, siapa yang harus berubah, dan bagaimana caranya untuk berubah. Kekurangan informasi dapat menjadi salah satu penyebab kecurigaan atau mispersepsi. ${ }^{6}$ Komunikasi termasuk salah satu komponen utama dalam informasi.

Partisipasi (Participation); peningkatan partisipasi adalah salah satu cara memperluas pemahaman akan perubahan. Partisipasi yang baik akan meningkatkan tingkat kerjasama. Sebaliknya, partisipasi yang kurang akan menimbulkan sikap perlawanan terhadap suatu perubahan dari kelompok yang menolak untuk berpartisipasi. Peningkatan partisipasi ini juga mencakup eliminasi dari ketakutan (fear) dalam menjalani perubahan. ${ }^{7}$

Kepercayaan (Trust); Kepercayaan adalah salah satu pilar utama, baik dalam perubahan maupun banyak hal lainnya. Kepercayaan populasi yang berubah pada otoritas perubahan akan membuat mereka lebih memiliki keinginan (willingness) untuk membuka hati juga memiliki efek mengurangi ketakutan (fear) terhadap perubahan tersebut.

Integritas (Integrity); Integritas yang baik dalam menjalankan suatu perubahan adalah satu keharusan. Tanpa integritas, populasi yang berubah berpotensi untuk mengalami kebingungan dan adaptasi yang berulang-ulang. Evaluasi (Evaluation); Evaluasi yang bertahap dan kontinyu merupakan elemen penting dalam perubahan. Evaluasi dapat memberikan gambaran kelebihan dan kekurangan dari suatu perubahan sehingga dapat dilakukan penyesuaian terhadap perubahan tersebut.

Penyesuaian (Adjustment); Penyesuaian berkaitan erat dengan aspek lainnya. Saat terjadi perlawanan, ada sebuah tuntutan untuk melakukan penyesuaian. Penyesuaian yang baik akan menurunkan tingkat perlawanan dari suatu populasi. Penyesuaian dapat memberikan ruang untuk suatu sistem berkembang menjadi lebih diterima dalam suatu populasi. Sebuah studi menyebutkan, timbal balik merupakan sesuatu yang esensial dalam membangun kerjasama, kepercayaan, dan komitmen. ${ }^{8}$

\section{Pembahasan}

Sebuah kerangka sistem kesehatan yang diperkenalkan oleh William Hsiao berupa

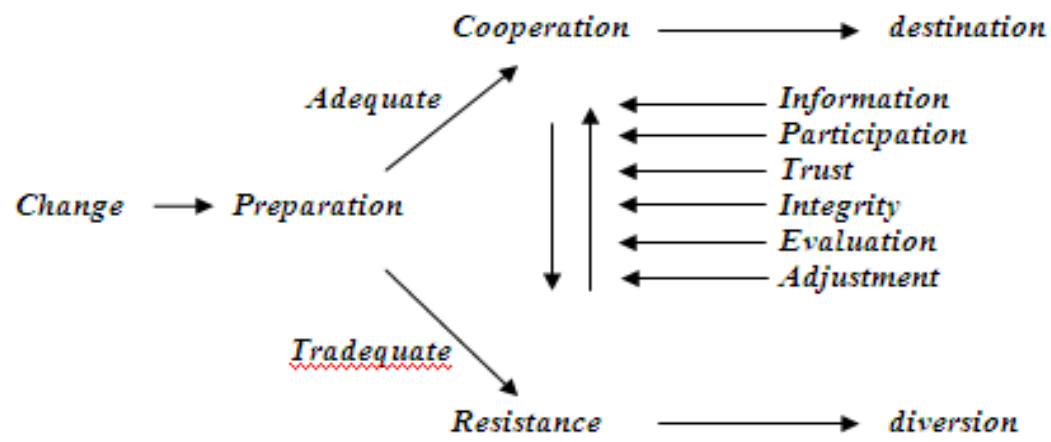

Cooperation-Resistance Theory

Gambar 2 Cooperation-Resistance Theory, Aditya Nugraha Nurtantijo (2015) 
Control Knobs membahas banyak mengenai perubahan pada sistem kesehatan. Ada 5 tombol kendali yang harus disesuaikan pada perubahan sistem kesehatan. Tombol-tombol itu adalah pembiayaan (financing), pembayaran (payment), organisasi (organization), regulasi (regulation), dan sikap (behavior). ${ }^{9}$ Penelitian ini menunjukkan hasil yang sejalan dengan studi ini karena dalam penyesuaian perubahan ternyata sistem informasi, partisipasi, kepercayaan, integritas, evaluasi, dan penyesuaian merupakan bagian dari penyesuaian kelima tombol ini. Aspek pembiayaan adalah perubahan utama dalam sistem kesehatan ini. Aspek pembayaran juga perlu disesuaikan karena sistem pembayaran yang berjangka memiliki tantangan yang berbeda. Aspek organisasi dalam penelitian ini adalah penyesuaian yang dilakukan oleh beberapa lembaga yang dilebur menjadi BPJS. Regulasi berkaitan dengan peraturan baik yang dikeluarkan pemerintah maupun lembaga BPJS. Sementara, penyesuaian sikap dilakukan oleh banyak pihak antara lain pemerintah, pihak ketiga, serta masyarakat yang menjadi peserta sistem.

Berdasarkan statistik secara global, hanya satu dari tiga perubahan profesional dalam organisasi yang dapat dianggap berhasil oleh pemimpinnya. ${ }^{10}$ Perubahan memiliki banyak tantangan dan kendala, salah satunya adalah penolakan dari orang yang melaksanakan perubahan tersebut. Penolakan adalah hasil pengalaman pribadi dan penilaian terhadap seberapa pihak lain dapat diandalkan. Penolakan juga merupakan respon awal dari perubahan. ${ }^{11}$ Aspek tersebut berkaitan erat dengan aspek kepercayaan yang ditemukan dalam penelitian ini. Kegagalan dalam perubahan banyak terjadi karena persiapan sistem baru yang dinilai belum melakukan persiapan secara menyeluruh saat memulai. Padahal, kesiapan dalam melakukan perubahan adalah salah satu cara untuk mengatasi penolakan dalam perubahan. Selain itu juga orang-orang perlu tahu visi dari perubahan tersebut. Saat orangorang yang melaksanakan perubahan tahu persis tujuan dari perubahan tersebut, mereka akan memiliki semangat lebih dalam melaksanakan perubahan. Perlu juga ditanamkan rasa tidak puas akan keadaan sekarang agar ada keinginan untuk berubah. ${ }^{12}$

Selain itu, kesiapan sebuah organisasi untuk berubah dapat diukur dari kesesuaian dari perubahan (appropriateness), manajemen, dan manfaat personal yang dirasakan oleh orang yang melaksanakan perubahan ${ }^{13}$ Beberapa faktor yang mempengaruhi ketersediaan obat di apotek tempat penelitian yaitu ketersediaan obat di apotek pusat karena pembelian obat hanya dilakukan di apotek pusat, sedangkan apotek cabang hanya memesan dari apotek pusat oleh karena itu keterlambatan pemesanan dapat berakibat kekosongan obat. Namun selain karena keterlambatan pemesanan, kekosongan obat juga dapat disebabkan juga kekosongan dari pihak Industri Farmasi melalui PBF. Keengganan PBF melayani pihak swasta yaitu apotek untuk pemesanan obat berdasarkan e-catalogue menjadi faktor yang dikeluhkan pihak swasta. Selain itu apotek jejaring juga membutuhkan dana yang cukup besar untuk memenuhi kebutuhan obat karena dengan adanya program BPJS, pasien menjadi sangat banyak yang harus dilayani.

Adanya perbedaan waktu pembayaran yang harus dibayarkan pihak apotek kepada PBF yaitu sekitar 30 hari dibandingkan waktu pembayaran klaim dari BPJS ke pihak apotek yaitu 75 hari memaksa apotek harus punya uang lebih atau dalam istilah mereka "uang tidur" yang jumlahnya cukup banyak, hal tersebut menyebabkan hanya apotek bermodal besar yang dapat bertahan untuk bekerja sama dengan BPJS. Limitasi dari penelitian ini adalah jumlah apotek yang terbatas. Penelitian dapat dibuat lebih besar dengan menambah luas wilayah yang diteliti sehingga jumlah responden dan apotek yang diteliti lebih banyak.

Kesimpulan dan Saran. Dari penelitian ini dapat ditarik beberapa kesimpulan, yaitu dampak negatif dari perubahan sistem pembiayaan yang terjadi adalah penolakan (resistance) yang menyebabkan penyimpangan (diversion) dari tujuan perubahan; Penyimpangan yang terjadi dalam penelitian ini adalah ketidaktersediaan obat dan kerugian pada apotek; Faktor-faktor yang memengaruhi ketidaktersediaan obat tersebut, yaitu regulasi dari BPJS yang berubah-ubah disertai pemberitahuan yang terlambat; pengadaan obat dari distributor yang memenangkan tender yang tidak sesuai kontrak kerja dengan BPJS; manajemen terutama dari BPJS dalam hal penyetujuan peresepan; sosialisasi program JKN kepada pihak-pihak terkait, antara lain dokter, apotek, dan peserta.

Saran untuk perbaikan dalam program ini, yaitu Menjalankan sistem regulasi yang konsisten. Jika ada perubahan, seharusnya pemberitahuan diberikan lebih dahulu sebelum diimplementasikan; Mengevaluasi kinerja Pedagang Besar Farmasi yang memenangkan tender untuk menyalurkan obat JKN; Mengevaluasi kinerja manajemen dari BPJS, terutama di BPJS Center di rumah sakit, dalam hal pelaksanaan peraturan dan persyaratan; Melakukan sosialisasi yang jelas dan menyeluruh bagi pihak-pihak yang terkait dalam JKN, antara lain dokter, apotek dan peserta. 


\section{Daftar Pustaka}

1. Organization WH. Fifty-Eight World Health Assembly. Geneva: 2005 16-25 May. Report No.: WHA58/2005/REC/1.

2. Undang-Undang No. 24 Tahun 2011 tentang Badan Penyelenggara Jaminan Sosial, (2011).

3. Zaharia Milena GD, Stancu Alin. Qualitative Research Methods: a. The Journal of the Faculty of Economics, University of Oradea. 2008;4(1):1279-83.

4. Tongco MDC. Purposive Sampling as a Tool for Informant Selection. Ethnobotany Research and Applications. 2007;5:147-58.

5. Thomas DR. A General Inductive Approach for Analyzing Qualitative Evaluation Data. American Journal of Evaluation. 2006;27(2):237-46.

6. Agboola AA. Managing Deviant Behavior and Resistance to Change International Journal of Business and Management 2011;6(1):235-42.

7. Kamel B. Reasons for Resistance to Change in the National Company for the Distribution of Electricity and Gas.
International Journal of Management and Strategy 2012;3(5).

8. Stephanie Hendrickson EJG. Legitimizing Resistance to Organizational Change: A Social Work Social Justice Perspective. International Journal of Humanities and Social Science. 2012;2(5):50-9.

9. W. Hsiao BS. Health Systems: Concepts and Deterministic Models of Performance. In: Health HSoP, editor. Boston 2008.

10. Meaney MaP, C. McKinsey global results: creating organizational transformations. The McKinsey Quarterly. 2008:1-7.

11. JF Fort LF. Resistance to change: the rest of the story. Academy of Management Review. 2008;33(2):362-77.

12. E J O'Connor CMF. Creating readinesss and involvement. Physician Exec. 2006;32:72-4.

13. B.J. Weiner HA, S.Y. Lee. Conceptualization and measurement of organizational readiness for change: a review of the literature in health services research and other fields. Med Care Res Rev. 2008;65:379-436. 